(The 3rd ICBS-2013)

\title{
THE DOSE VARIATIONS EFFECT OF Centella asiatica ETHANOL EXTRACT ON ESCAPE LATENCY'S DISTANCE MORRIS WATER MAZE AFTER CHRONIC ELECTRICAL STRESS
}

\author{
Dea Amelia Yolanda' ${ }^{1}$, Dwi Cahyani Ratna Sari², Mawaddah Ar Rochmah², Sri Suharmi ${ }^{3}$ \\ 1)Undergraduated Student of Faculty of Medicine, Gadjah Mada University. ${ }^{2}$ Department of Anatomy, Embriology \\ and Anthropology, Faculty of Medicine, Gadjah Mada University. ${ }^{3}$ Departement of Pharmacology and Therapy, \\ Faculty of Medicine, Gadjah Mada University. Correspondence author: deaameliayolanda@yahoo.co.id
}

\begin{abstract}
Centella asiatica sp. (pegagan) has neurotropic and neuroprotective properties which inhibit deterioration of memory because of chronic electrical stress. Studies about effective dose of Centtela asiatica still continued. This study was conducted to discover the influence of pegagan extract's dose variation intake towards memory after chronic stress. This study uses that true experimental design with pretest-posttest control design. Fifteen male Sprague Dawley rats were divided into three groups randomly. Every groups are treated with chronic electrical stress for 4 weeks and aquades (KN), 300 (KN1) or $600 \mathrm{mg} / \mathrm{kgBW} / \mathrm{day}$ (KP2) of Centella asiatica. The escape latency distance measure using Morris water maze was used to assess rats' memory. Data were analyzed using the Kolmogorov-Smirnov, ANOVA and paired t-test. The average of escape latency distance before chronic electrical stress were $5,71 \pm 0,77 \mathrm{~m}(\mathrm{KN}) ; 4,29 \pm 0,36 \mathrm{~m}(\mathrm{KP} 1) ; 3,81 \pm 0,47 \mathrm{~m}$ (KP2) and after chronic electrical stress were $1,50 \pm 0,05 \mathrm{~m}(\mathrm{KN}) ; 1,55 \pm 0,04 \mathrm{~m}(\mathrm{KP} 1) ; 1,82 \pm 0,11 \mathrm{~m}(\mathrm{KP} 2)$. There were significant differences among groups after chronic electrical stress on day- $1(p=0,005)$ and day- $3(p=0,001)$. There were significant differences $(p<0,05)$ for 3 days of escape latency test $(K N), 5$ days of escape latency test (KP1) and 2 days of escape latency test (KP2) from 6 days of memory measurement. In conclusion, dose variation of Centella asiatica did not affect to latency distance using Morris water maze. Ethanol extract of Centella asiatica with doses $300 \mathrm{mg} / \mathrm{kgBW} /$ day could stimulate increasing memory formation after chronic electrical stress better.
\end{abstract}

Key words: Centella asiatica - chronic electrical stress- memory-Morris water maze.

\section{INTRODUCTION}

Increasingly complex needs of modern era demanding human to work with more loads to meet those needs. The work load will affect human physical and psychological, then inducing stress. The incidence of life with stress correlates with disease conditions in humans. Research reveals that there was correlation between the incidence of life with stress and disease conditions in humans. Study reveals that the external environments such as financial problems, stress in workplace, personal relationship, health and the things that bothers were the biggest causes of stress in modern society (Holmes \& Rahe,1967).

Stress declines memory function through activating hypothalamus-pituitary-adrenal (HPA) axis. HPA axis gives negative feedback that leads to neurodegeneration of nerve cells in the brain, especially in hippocampus, a place for memory consolidation (Bowman et al., 2003).

Centella asiatica (pegagan) has many chemical compounds content. Centella asiatica has 36 derivates of asiatic acid with neuroprotectif effect. Three of those derivative compounds have neuroprotective effect. Its antioxidant effects are equivalent with glutathione, glutation peroxides and some other antioxidant enzyms (Orhan, 2012).

Morris water maze is a tool that is used to assess memory in rat (Hooge \& Deyn, 2001). The parameters that are used are distance, duration and speed of rat to reach the platform ${ }^{5}$.

ISSN 2413-0877 @ 2015 The Authors.

Published by KnowledgeE Publishing Services This is an open access article under the CC BY-NC-ND license (http://creativecommons.org/licenses/by-nc-nd/4.0)

Selection and Peer-review under responsibility of the 3rd ICBS-2013

Doi http://dx.doi.org/10.18502/kls.v2i1.134 
It also functions to evaluate the effect of neurotrophic agent to memory function (Alvin, 2009).

We used rat for this study due to this animal is standard animal in maze trial to assess learning and memory process (Hooge \& Deyn, 2001) and to minimize ovarian hormone's effect.

Many studies had been done to assess the effect of Centella asiatica in memory (Astari et al., 2012; Belcaro, 2011; Gupta \& Flora, 2006; Sari, 2011; Sari et al., 2012; Sasmita et al., 2012; Magarinos et al., 1997). Objective of this study is to discover the affect of dose variations effect of Centella asiatica ethanol extract on escape latency's distance Morris water maze after chronic electrical stress.

\section{MATERIALS AND METHODS}

Fifteen male Sprague Dawleyrats were divided into three groups randomly. Every groups are treated with chronic electrical stress for 4 weeks and aquades (KN), 300mg/kgBW/day (KN1) or $600 \mathrm{mg} / \mathrm{kgBW} /$ day (KP2) of Centella asiatica.

Before administration of Centella asiatica ethanol extract and chronic electrical stress, rats were tested with escape latency (hidden platform method) using Morris water maze for 8 days. Day- 1 and day- 2 is used as training for rats. From day-3 to day- 8 were the days to record for duration and distance for rat to reach the platform. Each trial was done twice a day.

Platform was placed in one of quadrants. Rats started to swim from one quadrant to different quadrant where platform was placed. The rat tried to locate the hidden platform under opaque color water. Around the maze was labeled with striking cues and the rats would memorize the cues to find platform. If in 90 seconds the rat could not find the platform, the mice was led to the platform and allowed to be on the platform for 30 seconds so that the rats could memorized the location of the platform relative to the cues around the maze. Then, the rat was removed from maze, dried and put into heater boxes while waiting for second trial. In the second trial mice re-tested in the same way the first trial. Rat placed in one quadrant of the maze and it would swim to find the platform. Once the rat found the platform, rats were removed from the pool, dried in a heater box and returned to the cage.

Duration and distance for rats to find the platform were measured and their activity to reach the platform was recorded by camera above the maze. Distance and duration to find the platform was measured using curvimetry and stopwatch.

After 8 days trial with escape latency (hidden platform method) Morris water maze before treatment, rats were treated for the provision of chronic electrical stress conditions and administration of Centella asiatica extract. Stress box is a box with dimension length $48 \mathrm{~cm}$, width $24 \mathrm{~cm}$, and height $32 \mathrm{~cm}$. The box was divided into 2 rooms which separated with a small opening door in the between so the rats could moved from one room to another room. Everyday rats were treated with chronic electrical stress for 10 minutes. Stress box supplied by wired grid floor with ampere $0.8 \mathrm{~mA}$ and voltage 50 volt. Electricity was supplied for 5 seconds frequently and have interval for 15 minutes in between.

After administering the treatment for 4 weeks, the rats were tested again with escape latency (hidden platform method) using Morris water maze for 8 days. Distance and duration to find the platform was measured using curvimetry and stopwatch. 


\section{RESULTS AND DISCUSSION}

\section{Observation of escape latency's distance before treatment}

Average of distance of rats to reach the platform started from day 1 to day 6 could be seen in Table 1. Test of normality showed that data were normally distributed $(p>0.05)$. Test for homogeneity with Lavene test showed that the data had same variant $(p>0.05)$. Therefore, further statistical analysis used was ANOVA (parametric). ANOVA test showed no significant difference ( $p>0.05$ ) on day 2 , day 3 , day 4 and day 5 on among groups before treatment. Significant difference between all group $(p<0.05)$ just found in day $1(p=0.011)$ and day $6(p=0,002)$. From these data it could be seen that the basic memory on each group before the treatment was the same

Table 1. Average distance for all group of rats to reach platform before treatment

\begin{tabular}{cccc}
\hline Day & \multicolumn{3}{c}{ Group } \\
\cline { 2 - 4 } & $\mathrm{KN}(\mathrm{m})$ & $\mathrm{KP} 1(\mathrm{~m})$ & $\mathrm{KP} 2(\mathrm{~m})$ \\
\hline $\mathbf{1}$ & $12,39 \pm 1,54$ & $7,13 \pm 0,40$ & $5,82 \pm 1,68$ \\
$\mathbf{2}$ & $6,35 \pm 1,99$ & $6,15 \pm 0,31$ & $5,65 \pm 1,11$ \\
$\mathbf{3}$ & $4,80 \pm 0,96$ & $4,06 \pm 0,57$ & $5,10 \pm 1,09$ \\
$\mathbf{4}$ & $4,60 \pm 1,28$ & $2,73 \pm 0,36$ & $2,16 \pm 0,30$ \\
$\mathbf{5}$ & $1,40 \pm 0,48$ & $3,65 \pm 0,32$ & $2,33 \pm 0,21$ \\
$\mathbf{6}$ & $4,73 \pm 0,75$ & $2,04 \pm 0,31$ & $1,79 \pm 0,20$ \\
\hline Avarage & $5,71 \pm 0,77$ & $4,29 \pm 0,36$ & $3,81 \pm 0,47$ \\
\hline
\end{tabular}

Note:

$\mathrm{KN}$ (Control group) :Aquadest and chronic electrical stress for 4 weeks.

KP1 (1 ${ }^{\text {st }}$ Group Trial) :Chronic electrical stress conditions and Centella asitica extract 300mg/kgBW/day for 4 weeks. KP2(2 $2^{\text {nd }}$ Group Trial) :Chronic electrical stress conditions and Centella asitica extract $600 \mathrm{mg} / \mathrm{kgBW} /$ day for 4 weeks.

\section{Observation of escape latency's distance after treatment}

Average of distance for all group of rats to reach platform on day 1 till to day 6 after the treatment shown in Table 2.

Table 2. Avarage distance for all group of rat to reach platform after treatment

\begin{tabular}{cccc}
\hline Day & \multicolumn{3}{c}{ Group } \\
\cline { 2 - 4 } & $\mathrm{KN}(\mathrm{m})$ & $\mathrm{KP} 1(\mathrm{~m})$ & $\mathrm{KP} 2(\mathrm{~m})$ \\
\hline $\mathbf{1}$ & $1,40 \pm 0,02$ & $1,43 \pm 0,05$ & $2,80 \pm 0,47$ \\
$\mathbf{2}$ & $1,41 \pm 0,11$ & $1,92 \pm 0,18$ & $1,96 \pm 0,16$ \\
$\mathbf{3}$ & $1,35 \pm 0,19$ & $1,61 \pm 0,44$ & $1,55 \pm 0,44$ \\
$\mathbf{4}$ & $1,82 \pm 0,25$ & $1,47 \pm 0,07$ & $1,54 \pm 0,07$ \\
$\mathbf{5}$ & $1,46 \pm 0,05$ & $1,39 \pm 0,06$ & $1,49 \pm 0,07$ \\
$\mathbf{6}$ & $1,56 \pm 0,06$ & $1,46 \pm 0,07$ & $1,61 \pm 0,08$ \\
\hline Avg & $1,50 \pm 0,05$ & $1,55 \pm 0,04$ & $1,82 \pm 0,11$ \\
\hline
\end{tabular}

ANOVA results were shown in Table 3. In escape latency on day 1 after chronic electrical stress, KP2 was significantly different to all other groups. KP2 against KN was significantly different $(p<0.05)$ and KP2 was significantly difference compare with KP1 $(p<0.05)$. On day 3 after treatment, KN was significantly different compare to all groups. KN-KP1 was significantly different $(p<0.05)$ and KN-KP2 was significantly different $(p<0.05)$. All the groups did not differ significantly on day 2 , day 4 , day 5 and Day 6 after stress. 
Table 3. Result of one-way ANOVA test

\begin{tabular}{ccccc}
\hline Day & $\begin{array}{c}\text { Sig. } \\
\text { between } \\
\text { groups }\end{array}$ & KN-KP1 & KN-KP2 & KP1-KP2 \\
\cline { 3 - 5 } & $0.005^{*}$ & 0.942 & $0.004^{*}$ & $0.004^{*}$ \\
\hline $\mathbf{2}$ & 0.057 & - & - & - \\
$\mathbf{3}$ & $0.001^{*}$ & $0.000^{*}$ & $0.002^{*}$ & 0.263 \\
$\mathbf{4}$ & 0.300 & - & - & - \\
$\mathbf{5}$ & 0.524 & - & - & - \\
$\mathbf{6}$ & 0.392 & - & - & - \\
\hline
\end{tabular}

*significant $(p<0.05)$

\section{The observation of escape latency's distance before and after treatment}

An increase of memory function before and after treatment were tested with paired ttest and shown in Table 4. In escape latency's distance, there was significant differences before and after treatment day 1 in KP1 and $K N(p<0,05)$, day 2 in KP1 and KP2 $(p<0,05)$, day 3 in $\mathrm{KN}, \mathrm{KP} 1$ and KP2 $(\mathrm{p}<0,05)$, day 5 in KP1. In day 6 in $\mathrm{KP} 1$ and $\mathrm{KN}(\mathrm{p}<0,05)$. In Day 4 there was no significant difference between before and after treatment in all groups $(p>0,05)$.

Table 4. Test result of paired t-test to show memory function improvement of rat before and after treatment

\begin{tabular}{|c|c|c|c|}
\hline \multirow[t]{2}{*}{ Day- } & \multicolumn{3}{|c|}{ Test result of paired t-test } \\
\hline & $\mathrm{KN}$ & KP1 & KP2 \\
\hline 1 & $0,002^{*}$ & $0,005^{*}$ & 0,203 \\
\hline 2 & 0,06 & $0,000^{*}$ & $0,029^{*}$ \\
\hline 3 & $0,024^{*}$ & $0,026^{*}$ & $0,035^{*}$ \\
\hline 4 & 0,124 & 0,052 & 0,083 \\
\hline 5 & 0.236 & $0,003^{*}$ & 0,16 \\
\hline 6 & $0,011^{*}$ & $0,049^{*}$ & 0,388 \\
\hline
\end{tabular}

*significant value $(p<0,05)$

\section{RESULT AND DISCUSSION}

There have been many studies that discussed the impact of stress on learning and memory (Bowman et al., 2003; Astari et al., 2012). Sustained damage in formatio hippocampi due to stress condition caused decreased of pyramidalis cell number (Astari et al., 2012; Sari et al., 2012), dendrites atrophy and decreased excitability of CA1 hippocampus (Tak et al., 2007). Chronic stress induces HPA (hypothalamus-pituitary-adrenal) pathway. In stress condition, hypothalamus secretes corticotrophin-releasing hormone $(\mathrm{CRH})$, then $\mathrm{CRH}$ will stimulate the secretion of adenocorticotropin hormone (ACTH) from pituitary to bloodstream, goes to adrenal gland that secretes glucocorticoid. Glucocorticoid binds its receptor in hippocampus (McEwen et al., 1998).

Interaction between glucocorticoid and its receptor in hippocampus inhibits glutamate uptake (McEwen et al., 1998). As a result, glutamate level will increase due to persistent glutamate secretion. It causes an increase of calcium flow. Increased of calcium flow in hippocampus will affect to neuron damage due to instability of cell membrane (Maggio \& Segal, 2010). 
Activation of glucocorticoid receptor also activates NMDA (N-Methyl-D-aspartate) receptor due to increasing glutamate level. An increase of glutamate in low frequency induces long-term depression (LTD) (Magarinos et al., 1997). In addition, activation of glucocorticoid receptor also leads to hiperpolarization of membrane resulting inactivation of NMDA receptor that plays role in LTP (long-term potentiation) process. As a consequences, inactivated NMDA may decrease LTP and increase LTD (Krzak et al., 2003.

Beside causing membrane cell instability, binding between glucocorticoid and its receptor also causes oxidative stress phenomena. Sustained oxidative stress in the hippocampus could lead to degeneration and atrophy of neurons in hippocampus (Morris et al., 2003). It causes a decrease of cognitive function as well as reduction of learning and memories.

Learning and memory process involves several regions of brain as cortex, amygdala, cerebellum and hippocampus. The process of memory formation mechanism is mediated by LTP, induction and expression of synaptic plasticity. Process from memory formation to memory recalling are a series of processes that include encoding, memory storage, consolidation and recall. Hippocampus is activated while that all are processed (Kumar et al., 2011).

Centella asiatica sp. is herbal plant that has an effect on cognitive function (Soumyanath et al., 2012). Role of Centella asiatica in improving memory after stress mediated by some mechanisms, such as an increase of dopamine biosynthesis that induces LTP. Dopamine biosynthesis will help to consolidate memories through LTP mechanism (Belcaro, 2011). Centella asiatica was able to regenerate neurons by stimulate neurit growth, increasing dendritic arborisation in basal and apical dendrite (Rao et al., 2007), extending dendrite and increasing branch spot of rat's neuron amygdala (Corwin, 2009). Centella asiatica is expected to decrease memories loss due to chronic electrical stress.

Brain has a blood brain barrier that control substances that are capable of reaching the brain through vascular so it can protect brain from exposure against dangerous material (Mook-Jung et al., 1999). Some active substances of Centella asiatica which be able to penetrate blood brain barrier are asiatic acid, madasiatic acid, asiaticosida and madecassosida (Rao et al., 2007).

Effect of Centella asiatica extract on memory formation could be seen from the difference of rats' performance before and after treatment. Differences in memory performance before and after treatment were analyzed with paired t-test. In KN, the process of memory formation before and after treatment was significantly different on day 1, day-3 and day-6, so that significant differences in $\mathrm{KN}$ occurred in 3 days from 6 days a memory test. In KP1, the process of memory formation before and after treatment was significantly different on day 1 , day 2, day 3, day 5 and day 6 so that significant differences in KN occurred 5 days from 6 days a memory test. In KP2 process of memory formation before and after treatment was significantly different on day 2 and day 3 so that significant differences in $\mathrm{KN}$ occurred2 days from 6 days a memory test. From these data it could be interpreted that Centella asiatica could increase memory performance after chronic electrical stress better in KP1 (dose of $300 \mathrm{mg} / \mathrm{kg} / \mathrm{day}$ ). This result is consistent with previous research showed that Centella asiatica extract at levels of $100-300 \mathrm{mg} / \mathrm{kg} /$ day could improve learning and memory in mouse with 
central nervous system toxicity (Rao et al., 2007).

Centella asiatica effects that improve learning and memory can be fascilitated by its component, such as Asiatic acid. It is the main component of Centella asiatica that increases nerve growth factor and acceleratea axon regeneration (Rao et al., 2007). Asiatic acid is able to regenerate neuron damage ${ }^{21}$ thus learning and memory processes in hippocampus are retained.

Other active substance which plays role in the neuroprotective and neurotrophic properties of Centella asiatica is asiaticoside (Orhan, 2012). Asiaticosida also enriched cognitive function (Soumyanath et al., 2012), stabilizing the balance of intracellular calcium ions levels so that neuron damage could be avoided, reducing free radical agent and reducing apoptosis (Grossmann \& Skinner, 1996). Both asiaticoside and asiatic acid could reduce free radical and reduce apoptosis (Oktanindi, 2009).

Previous studies also showed that ethanol extract of Centella asiatica $300 \mathrm{mg} / \mathrm{kg} / \mathrm{day}$ could increase the memory better than aquadest (Subathra et al., 2005). Centella asiatica extract dose $300 \mathrm{mg} / \mathrm{kg} /$ day administrated for 60 days reduced lipid peroxidation and protein carbonyl and improved antioxidant status in some regions in the rat brain, including hippocampus. Centella asiatica extract dose $300 \mathrm{mg} / \mathrm{kgBW} /$ day also improve rat's behaviour (Soumyanath et al., 2012; Irawan et al., 2012). Centella asiatica antioxidant properties that act as a neuroprotective agent are capable to prevent aging-related changes in rats caused oxidative damage (Irawan et al., 2012). Research on humans with elderly subjects revealed Centella asiatica extract $400 \mathrm{mg}$ administrated 2 times a day for 3 months could increase the function of the orientation and memory (Sari et al., 2012). Centella asiatica dose 300 $\mathrm{mg} / \mathrm{kg} / \mathrm{day}$ was also able to protect the brain from damage caused by arsenic-induced oxidative stress ${ }^{7}$. Centella asiatica extract dose $300 \mathrm{mg} / \mathrm{kgBW}$ was able to prevent the reduction of cell proliferation in adult rat hippocampal after chronic stress ${ }^{27}$.

Memory formation differences between groups are tested with one-way ANOVA test, then continued with post-hoc analysis. It was demonstrated that in day-1 after treatment, escape latency distance for KP2 was significant longer than KP1 $(p<0.05)$. We also found that KP2 escape latency distance on the day-1 was longer than KP1 distance on the day-1. Difference between groups on day-2, day-3, day- 5 and day 6-were not statistically significant. We concluded that in this study the dose variation Centella asiatica extract $(300 \mathrm{mg} /$ $\mathrm{kgBW} /$ day and $600 \mathrm{mg} / \mathrm{kgBW} /$ day) did not show any significant differences in the process of memory formation after chronic electrical stress. It might due to optimum dose of Centella asiatica to increase memories production was under $600 \mathrm{mg} / \mathrm{kgBW} /$ day.

\section{CONCLUSION}

We proposed that extract of Centella asiatica $300 \mathrm{mg} / \mathrm{kgBW} /$ day might increase memories formation of rats after chronic electrical stress that is showed with reduction of distance rat (Sprague Dawley) to reach platform escape latency using Morris water maze test.

\section{ACKNOWNLEDGMENT}

Appreciate and special thankful Dr. dr. Djoko Prakosa, PA(K) and dr.Nur Arfian, Ph.D for discussion and comment and Mr. Mulyana for helping animal experiment. 


\section{REFERENCE}

Alvin, V. Terry. Jr. 2009. Methods of Behavior Analysis in Neuroscience, $2^{\text {nd }}$ edition : Chapter 13 Spatial Navigation (Water Mask) Tasks. Boca Raton (FL) : CRC Press.

Astari, N.A., D.C.R. Sari, S. Aswin, and S. Suharmi. 2012. The effect of administration pegagan etanolic extract on the number of hippocampal CA3 pyramidal neurons. Proceedings of the $23^{\text {rd }}$ European Students' Conference. 333; Germany: Cdayté.

Belcaro, G., F.X. Maquart, M. Soccianti, M. Dugall, M. Hosoi, M.R. Cesarone. 2011. TECA (Titrated Extract of Centella asiatica): new microcirculatory, biomolecular, and vascular application in preventive and clinical medicine. Panminerva Med53 (3 Suppl 1): 10518.

Bowman, R.E., K.D. Beck, and V.N. Luine. 2003. Chronic stress conditions effects on memory: sex differences in performance and monoaminergic activity. Hormone and Behavior . 43: 48-59.

Corwin, E.J. 2009. Buku Saku Patofisiologi. $3^{\text {rd }}$ Ed. Jakarta: EGC.

Grossmann, M., and M.H. Skinner. 1996. A simple computer based system to analyze Morris water maze trials on-line. J.Neurosci. Method 70: 171-175.

Gupta, R., and S.J. Flora. 2006. Effect of Centella asiatica on arsenic induced oxidative stress conditions and metal distribution in rats. J Appl Toxicol26(3):213-22.

Holmes, T.H., and R.H. Rahe. 1967. The Social Readjusment Scale. J. Psychosomatic Research. 11:213-8.

Hooge, R., and P.P.D. Deyn. 2001. Application of the Morris water maze in the study of learning and memory. Brain Research Reviews. 36: 60-90.

Irawan, V., R. Susilowati, Y. Taihuttu, N. Wiyono, and T.W. Pangestiningsih. 2012. Protective Effect of Centella asiatica (L.) Urban Etanolic Extract on Hippocampal Call Proliferation of Adult Rat in Chronis Stress conditions Condition. Proceedings Pertemuan IImiah Nasional PAAI XIV. 60; Denpasar: Komisariat PAAI Denpasar.

Krzak, J.S., I.Z. Lupina, K. Czerny, M. Stepniewska, and A. Wrobel. Neuroprotective effect of ACTH (4-9) in degeneration of hippocampal nerve cells cause dexamethasone: morphological, immunohistochemical and ultrastructural studies. Acta Neurobiol Exp 2003. 63: 1-8.

Kumar, A., A. Prakash, and S. Dogra. 2011. Centella asiatica Attenuates D-GalactoseInduced Cognitive Impairment, Oxidative and Mitochondrial Dysfunction in Mice. J. Alzheimer's Disease :[9p.].

Magarinos, A.M., J.M.G. Verdugo, and B.S. McEwen. 1997. Chronic stress conditions alters synaptic terminal structure in hippocampus. Neurobiology 94: 14002-8.

Maggio, N., and M. Segal. 2010. Corticosteron regulation of synaptic plasticity in the hippocampus. Scientific World. 10: 462-9.

McEwen, B.S., J.S. Flier, and B.S. Underhill. 1998. Protective and damaging effects of stress conditions mediators. N. Engl.J. Med. 338(3): 171-9.

Mook-Jung, I., J.E. Shin, S.H. Yun, K. Huh, J.Y. Koh, H.K. Park. 1999. Protective effect of asiaticoside derivates against beta amyloid neurotoxicity. J.Neuri.Res 58(3):417-25.

Morris, R.G.M., E.I. Moser, G. Riedel, S.J. Martin, J. Sandin, M. Day. 2003. Elements of 
Neurobiological Theory of the hippocampus: the role of activity-dependent synaptic plasticity in memory. Phil. Trans. R.Soc. Lond. 773-786.

Oktanindi, F. 2009. Pengaruh pemberian ekstrak etanol pegagan (Centella asiatica L.) terhadap memori spasial. Yogyakarta: Universitas Gadjah Mada. Skripsi.

Orhan, I.E. 2012. Centella asiatica (L.) Urban: From Traditional Medicine to Modern Medicine with Neuroprotective Potential. Eviandce-Based Complementary and Alternative Medicine. [8p.].

Rao, K.G.M., S.M. Rao, and S.G. Rao. 2007. Enhancement of Amydaloid Neural Dendritic Arboriderivateion by fresh Leaf Juice of Centella asiatica (Linn) during Growth Spurt Period in Rats. eCam 1-8.

Sari, D.C.R. 2011. The Relationship between Memory, CA1 Hippocampus and Neuroglia after Centella asiatica Leaf Extract's Administration in Stress conditions-Induced Rat (Rattus novergicus). Proceedings of the $2^{\text {nd }}$ International Joint Symposium. 12-9; Yogyakarta: Faculty of Med Univ Gadjah Mada.

Sari, D.C.R., S. Aswin, S. Suharmi, M. Romi, and U. Tranggono. 2012. The relationship between spatial memory and the thickness of hippocampal CA1 pyramidal layer in Stress conditions-induced rats (Rattus novergicus) after Centella asiatica leaf extract's administration. Nutrition\&Dietetics. 69 (Suppl 1 September 2012): 62.

Sasmita, P.K., T. Djuartina, and H. Uinarni. 2012. Effect of Extract of Gotu Kola (Centella asiatica) on Cogntive Function in Elderly. Proceedings Pertemuan IImiah Nasional Perhimpunan Ahli Anatomi Indonesia X1V. 60; Denpasar: Komiariat PAAI Denpasar.

Soumyanath, A., Z. Yong-Ping, E. Henson, Wadsworth, J. Bishop, and B.G. Gold. 2012. Centella asiatica Extract Improves Behavioral Deficits in a Mouse Model of Alzheimer's Disease: Investigation of a PossibleMechanism of Action. Int. J. Alzheimer's Disease [9p.].

Subathra, M., S. Shila, M.A. Devi, and C. Panneercellvam. 2005. Emerging role of Centella asaitca in imporeving age-related neurological antioxiandt status. Exp Geronto/ 40(89): 707-15.

Tak, P.W., J.G. Howland, J.M. Robillard, Y. Ge, W. Yu, A.K. Titterness. 2007. Hippocampal long-term depression medates acte stress conditions induced spatial memory retrieval impairment. PNAS. 104(27):11471-6. 